
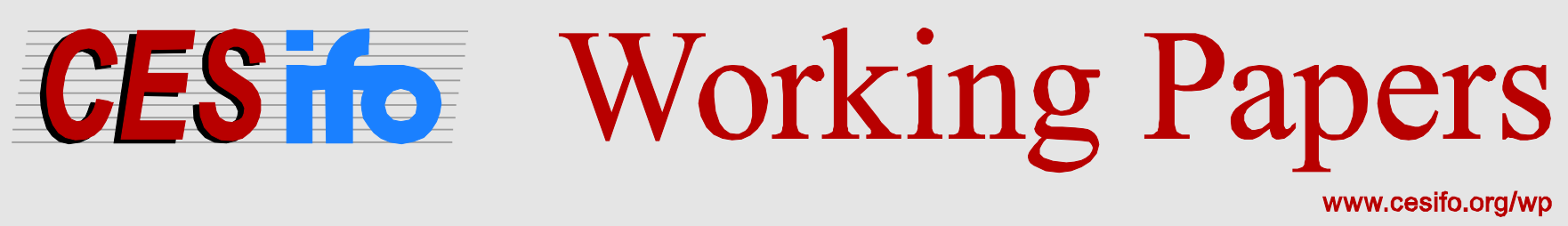

\title{
The Impacts of Feed-in Tariffs on Innovation: Empirical Evidence from Germany
}

\author{
Christoph Böhringer \\ Alexander Cuntz \\ Dietmar Harhoff \\ Emmanuel Asane Otoo
}

\author{
CESIFO WORKING PAPER NO. 4680 \\ CATEGORY 10: ENERGY AND CliMATE ECONOMICS \\ MARCH 2014
}

An electronic version of the paper may be downloaded

- from the SSRN website:

- from the RePEc website:

- from the CESifo website:

WWW.SSRN.com

www.RePEc.org

www.CESifo-group.org/wp

\section{CESifo}




\title{
The Impacts of Feed-in Tariffs on Innovation: Empirical Evidence from Germany
}

\begin{abstract}
Feed-in tariffs under the Renewable Energy Sources Act, the so-called Erneuerbare-EnergienGesetz (EEG), have triggered a massive expansion of electricity from renewable energy sources in Germany over the last decade. The increase in non-competitive renewable power generation though went hand in hand with a substantial rise in electricity prices with consumers paying for the renewable energy subsidies. The high cost burden has provoked an intense public debate on the benefits of renewable energy promotion. In this paper, we assess one popular justification for feed-in tariffs, i.e., induced innovation as a positive spillover externality. Based on regressions with a time-technology fixed effect negative binomial model, we find that innovation impacts of feed-in tariffs under the EEG are insignificant.
\end{abstract}

JEL-Code: C230, H230, O380.

Keywords: renewable energy promotion, feed-in tariffs, innovation, negative binomial regression.

\author{
Christoph Böhringer \\ Department of Economics \\ University of Oldenburg \\ Ammerländer Heerstrasse 114-118 \\ Germany - 26129 Oldenburg \\ boehringer@uni-oldenburg.de \\ Dietmar Harhoff \\ Max Planck Institute for Intellectual \\ Property and Competition Law \\ Marstallplatz 1 \\ Germany-80539 Munich \\ dietmar.harhoff@ip.mpg.de
}

\author{
Alexander Cuntz \\ Expert Commission for Research and \\ Innovation \\ Pariser Platz 6 \\ Germany - 10117 Berlin \\ alexander.cuntz@stifterverband.de \\ Emmanuel Asane Otoo* \\ Department of Economics \\ University of Oldenburg \\ Ammerländer Heerstrasse 114-118 \\ Germany - 26129 Oldenburg \\ asane.otoo@uni-oldenburg.de
}

* corresponding author 


\section{Introduction}

Subsidies for electricity production from renewable energy sources have been on the agenda of German energy policies since the early 1990s. A central justification for renewable energy promotion policy is climate protection, i.e., the reduction of anthropogenic greenhouse gas emissions emerging to a large extent from the combustion of fossil fuels. Germany aims at curbing greenhouse gas emissions compared to 1990 levels by $40 \%$ by the year 2020, and by $80 \%$ to $90 \%$ by 2050 . A major contribution to emission reduction should thereby stem from the "greening" of the power sector with a target share of renewable electricity production in total electricity consumption of 35\% by 2020 and $80 \%$ by 2050 .

The primary policy instrument for pushing power generation from renewable energy sources in Germany are feed-in tariffs which guarantee purchases of green power at fixed prices over longer periods. Feed-in tariffs are differentiated by technology to outweigh technologyspecific cost disadvantages compared to conventional power generation based on fossil or nuclear fuels. Between 1991 and 1999, feed-in tariffs were prescribed through the Electricity Feed-in Law, the so-called Stromeinspeisungsgesetz (SEG). The SEG obligated grid operators to purchase green power at a minimum price calculated as a share of the average revenue for electricity in past years. In 2000, the SEG was replaced by the Renewable Energy Sources Act, the so-called Erneuerbare-Energien-Gesetz (EEG). Compared to the preceding SEG, the EEG increased feed-in-tariffs in particular for photovoltaic and included additional technologies such as geothermal energy into the promotion scheme. The EEG guarantees investors above-market fees for renewable energy for 20 years from the point of installation. An EEG surcharge - equal to the difference between feed-in tariffs paid by utilities for renewable energy and the revenue from energy fed into the grid - is added to the bills of electricity consumers.

The subsidies granted under the SEG and EEG triggered a massive growth in renewable electricity production. The share of renewables increased from 3.1\% in 1990 to $6.8 \%$ in 2000 and to $22.9 \%$ in 2012. Within the various renewable technologies, wind power currently commands the highest share (33.8\%) followed by biomass (30\%), photovoltaic (20.6\%) and hydropower (15.6\%) (BMU 2013).

Over the last years, the German feed-in tariff programs came increasingly under fire for being extremely costly and ineffective as an instrument for climate protection (Frondel et al. 2010). Between 2000 and 2013 the effective subsidies under the EEG increased from less than a billion euro to roughly 20 billion euro in 2013. As a consequence, the EEG surcharge on 
households' electric bills has reached 5.277 eurocent/kWh in 2013 with a further announced increase to 6.24 eurocent/kWh in 2014. The EEG surcharge thus accounts roughly for one fourth of the national average household electricity price.

The EEG has been particularly criticized due to its ineffectiveness with respect to greenhouse gas emission abatement. As a matter of fact, greenhouse gas emissions for energy-intensive industries (including the power sector) in the EU are capped through an emissions trading system. Subsidies to renewable power production will simply reallocate emissions across these energy-intensive industries while the overall cost of the emission cap will rise due to excessive abatement from expansion of renewable energies and too little abatement from other mitigation opportunities such as fuel switching (Böhringer et al. 2009, 2014). Protagonists of renewable energy promotion therefore strive after additional reasons to justify green subsidies. One popular argument refers to external economies of scale due to technology spillovers. Incomplete appropriation of knowledge spillovers to competitors may result in substantial underinvestment in technological innovation by firms relative to the social optimum (Mitchell et al. 2011). Expansion of renewable power capacity and production could generate spillovers that are external to the individual firm and thus might justify subsidies to correct for market failures. In this vein, the EEG with its long-term take-and-pay provisions is hoped to encourage research and development (R\&D) and to spur technological innovation.

We scrutinize the innovation argument for renewable energy promotion. Our analysis investigates the impact of feed-in-tariffs on technological innovation measured by patent counts in renewables. To the best of our knowledge, this paper is the first to empirically establish the nexus between feed-in tariffs and innovation in renewables under the EEG policy framework in Germany.

Our results based on regressions with a time-technology fixed effect negative binomial model cast doubts on the innovation hypothesis of the EEG. Innovation impacts of feed-in tariffs under the EEG are insignificant in the case of photovoltaic, wind and geothermal while the coefficients show even significant negative innovation impacts in the case of biomass and hydro technologies.

The innovation impacts of renewable promotion policies have been investigated in various empirical studies. Johnstone et al. (2010) examine the effects of environmental policies on technological innovations in renewable energy using a panel data set across 25 countries and 
across several sources of renewable energy. ${ }^{1}$ They provide evidence that the effectiveness of alternative policy measures depends on the specific energy source. ${ }^{2}$ Furthermore, they conclude that broader market-based regulation such as tradable green certificates are more likely to induce innovation in renewable technologies which are close to competitive while specific feed-in tariffs are needed to induce innovation in more costly energy technologies such as solar power. They also find that renewable-specific public R\&D spending is a significant determinant of innovation in renewable energy overall, with its effects most noticeable for wind, solar and geothermal technologies.

The cross-country study by Walz et al. (2011) focuses on wind power only, but accounts for international spillovers via trade. The study includes additional explanatory variables beyond public R\&D spending to capture the implications of green policy legitimacy and stability. The results indicate that an overall favorable policy environment encourages patenting in wind power. Furthermore, there are significant trade effects - proxied by the volume of exports in wind power - on innovation. Peters et al. (2012) for photovoltaic as well as Dechezlepretre and Glachant (2013) for wind power show that domestic and foreign demand-pull policies (e.g. production tax credits) in OECD countries trigger innovation within national borders and also create country-level innovation spillovers. ${ }^{3}$ Both cross-country studies by Walz et al. (2011) and Peters et al. (2012) find that public R\&D expenditures on specific renewable technologies have significant positive impact on innovation in renewable energy. As to Germany, Wangler (2012) identifies a positive correlation between renewable energy promotion and innovation at the aggregate technology level.

However, all the above studies except Wangler (2012) focus on cross-country analysis without considering the innovative effects of specific renewable policies at the individual country level. Additionally, most of the empirical studies so far bundle all demand pull policies together and thus fall short of differentiating the specific innovative effects of the different demand pull policies.

The remainder of our paper is organized as follows. In section 2, we lay out data sources and describe the econometric model settings underlying our econometric estimations. In section 3, we discuss results. In section 4, we draw policy conclusions.

\footnotetext{
${ }^{1}$ These include wind, solar, ocean, geothermal, biomass, and waste-to-energy.

${ }^{2}$ Price-based instruments such as tax measures and investment subsidies are found to be most effective in encouraging innovation in solar, biomass, and waste-to-energy. Quantity-based policy instruments such as standards or tradable certificates turn out to be most effective in spurring innovation in wind power.

${ }^{3}$ The two studies differ with regard to the marginal effect of domestic and foreign demand (policies) on patented innovation. Dechezlepretre and Glachant (2013) identify factors driving the international diffusion of inventions. They are able to show that local demand for wind power exerts a positive influence on technology inflows.
} 


\section{Empirical framework: data and model specifications}

Our empirical analysis is conducted by constructing two sets of longitudinal panels from 1990-2009 and from 2000-2009. The first dataset integrates both SEG and EEG regulatory policies whereas the second dataset focuses on the EEG regulation only. We can distinguish five different renewable technologies: photovoltaic, wind, geothermal, biomass and hydro. Appendices 3 and 4 show the descriptive statistics and the correlation matrix of all variables used in the analysis.

\subsection{Measuring innovation activity}

Patent-based indicators are in wide-spread use for assessing the rate of technical change, measuring the competitive positions of firms, and evaluating scientific progress and knowledge spillovers (Danguy et al. 2010). One concern in using patent counts as an indicator for innovation output is that patents differ significantly in quality (value) and the propensity to patent also varies across sectors and countries. On the other hand, there are very few examples of economically significant inventions which have not been patented (Dernis and Guellec, 2002; Dernis and Kahn, 2004) and patent data therefore is perceived as an appropriate indicator for innovation output or knowledge production (Schmookler, 1966; Griliches, 1990; Wakasugi and Koyata, 1997).

We use patent counts to proxy innovation in renewable energy technologies. The data is compiled from the PATSTAT database (EPO 2013) and consists of patent applications with Germany as the priority country. Following Johnstone et al. (2010), Wu and Mathews (2012), and Wangler (2012) we identify renewable patent counts based on the International Patent Classification (IPC) code (see Appendix 1). We aggregate the patent counts into five renewable technology classes and use the priority date to capture the occurrence of innovation since it is closest to the actual date of invention.

Figure 1 depicts renewable patent applications by type of technology from 1990 to 2009. For photovoltaic and wind, we observe a relatively smooth increase in patenting activities between 1990 and 2004; from 2005 onwards, there is a sharp increase in patenting for photovoltaic and wind. On the other hand, patent applications for biomass, geothermal and hydro remain relatively stable throughout the observation period. 


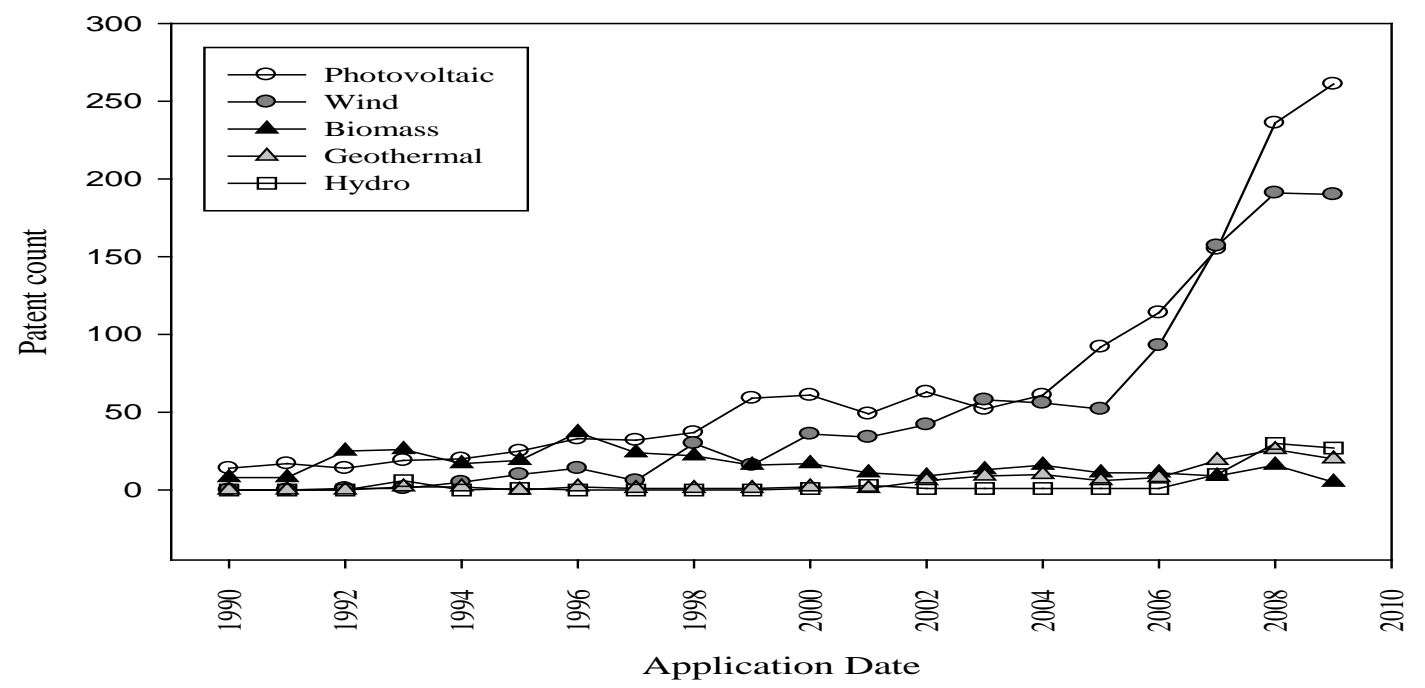

Figure 1: Patent count for renewable technologies

\subsection{Determinants of innovation}

Our central explanatory policy variable for innovation in renewable technologies are feed-in tariffs. In the regression analysis for the EEG with the dataset ranging from 2000 to 2009 we employ the technology-specific feed-in tariffs in Euro Cent/kWh as the explanatory policy variable directly. For the integral analysis of the SEG and EEG regimes captured by the dataset ranging from 1990 to 2009 we use installed capacity as a proxy for the two different policy environments. ${ }^{4}$ Appendix 2 lists the feed-in tariffs under the EEG while technologyspecific installed capacities (measured in MW) are displayed in Figure 2. Data on EEG feedin tariffs are based on the official annual statements of accounts by the German grid operators (EEG, 2012) while installed capacity data stems from the German Federal Ministry for Environment, Nature Conservation and Nuclear Safety (BMU 2013). Figure 2 indicates that hydro is the most important renewable energy source until 1999 when wind takes prominence over all other renewable energy sources. Wind installed capacity increases drastically under the EEG from 2000 onwards, while the strong increase of biomass and photovoltaic does not come in before 2003. Hydro capacity remains fairly constant throughout the SEG and EEG periods.

\footnotetext{
${ }^{4}$ The EEG adopted much higher feed-in tariffs than the SEG. Contrary to the SEG where annual tariff rates are set to a fraction of the consumers' electricity price paid in the preceding last-but-one year, the EEG fixes tariff rates exogenously over a 20 year horizon.
} 


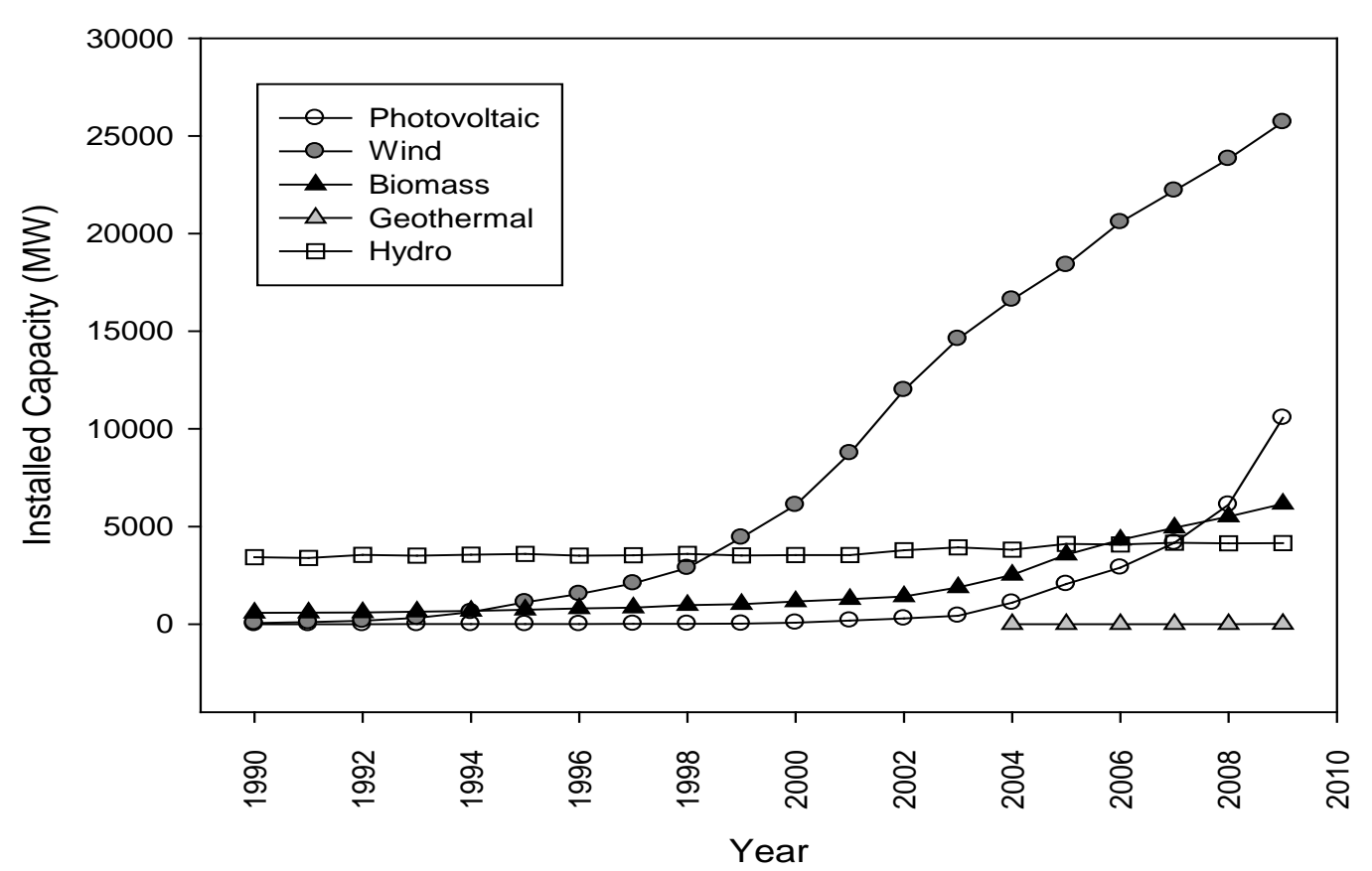

Figure 2: Installed capacity of renewable technologies

As laid out in the cross-country studies by Walz et al. (2011) as well as Peters et al. (2012) public R\&D expenditures might be a significant driver of innovation in renewable technologies. We thus include public $R \& D$ as a control variable in our estimations. For the parameterization of public $R \& D$ we use government expenditures on energy $R \& D$ disaggregated by type of renewable technology (IEA, 2011, 2013). ${ }^{5}$ The technology-specific public R\&D funding as shown in Figure 3 is measured in million EURO (2012 prices). Figure 3 shows that reported public R\&D funding for hydro is almost negligible throughout our observation period while R\&D funding for wind, geothermal and biomass is relatively low compared to photovoltaic with the peak in photovoltaic R\&D being in the early 1990s.

\footnotetext{
${ }^{5}$ The IEA database comprises all programs that focus on sourcing energy, transporting energy, using energy and enhancing energy efficiency.
} 


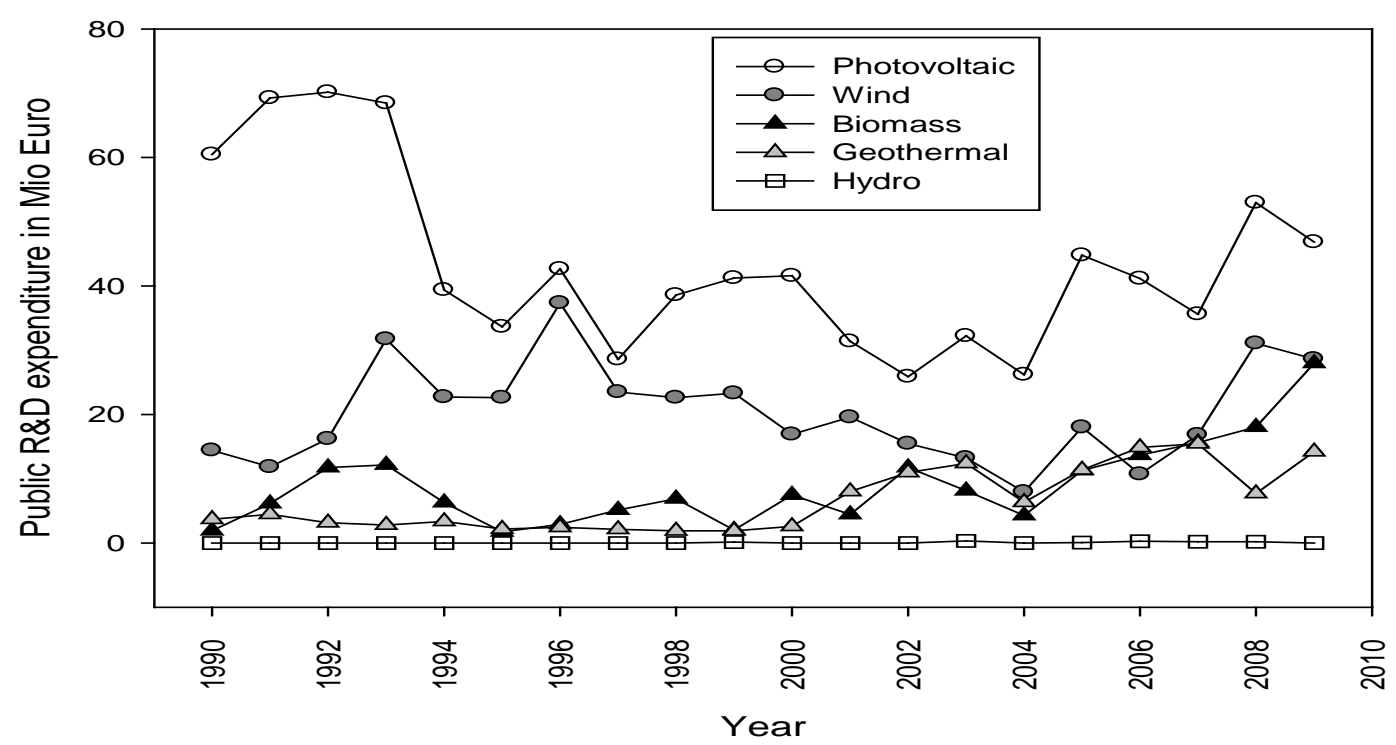

Figure 3: Public R\&D expenditure on renewable technologies

We also include overall industrial R\&D expenditures in Germany (OECD, 2013) measured in million EURO (2012 prices) as a control variable. Additionally, electricity market variables may as well determine the extent of innovation in renewables. For example, increases in electricity prices should increase incentives for innovation in renewable power technologies. Likewise, a growing market for electricity which is mirrored by trends in electricity net consumption should also stimulate incentives to innovate in renewables. The data for the consumer price for electricity in Germany (indexed to the base year 2010), and total electricity net consumption (in Billion kWh) are obtained from the German Federal Statistical Office (GSO 2013) and the EIA's International Energy Statistics Database (EIA 2013), respectively. In order to capture institutional changes in patenting propensity we also incorporate total patent counts from PATSTAT for all patent applications in Germany as a control variable.

\subsection{Model specification}

Patent count data is often characterized with zero and low positive integer values because most firms do not apply for patents regularly. This implies that conventional ordinary least square estimation which assumes that the dependent variable is continuous, normally distributed, and linearly related to the independent variables yields biased and inconsistent estimates. Due to the count data characteristics of our dependent variable (patent), we use count models (Maddala 1983; Hausman et al. 1984; Cameron and Trivedi 1998). A formal test of the null hypothesis of equidispersion indicates the presence of significant overdispersion. We therefore adopt a negative binomial model. Beside the overdispersion 
property of our data, the negative binomial model is also generally found to be more efficient (Lawless 1987; Blundell et al. 1995).

To test the relationship between patents in specific renewable technologies and feed-in tariffs (thereafter referred as FIT), we specify our basic negative binomial model as follows: ${ }^{6}$

$$
\text { Patent }_{i, t}=\exp \left[\beta_{1}\left(F I T_{i, t}\right)+\beta_{j}\left(Z_{t}\right)+\alpha_{i}+\lambda_{t}\right]+\xi_{i, t}
$$

where $i=1, . ., 5$ indexes the five different renewable technologies (photovoltaic, wind, biomass, geothermal and hydro) and $t=1990, . ., 2009$ indexes the observation year. $\mathrm{Z}_{t}$ represents all other control variables, in our case: public R\&D funding, total electricity net consumption, the consumer price index of electricity, total industrial private $R \& D$ expenditures and total patent counts. We include a time lag (t-1) to incorporate the lag between variables such as public R\&D and innovative output while $\left(\alpha_{i}\right)$ and $\left(\lambda_{i}\right)$ captures both technology and time fixed effects, respectively. While the inclusion of technology fixed effect control time-invariant technology-specific unobservable fixed effects, the time fixed effect control aggregate time trends in patenting dynamics and hence, captures unexpected variation or technological shock which may affect the innovation process. All other residual variation is captured in the error term $\left(\xi_{i, t}\right)$.

To segregate the aggregate FIT variable into technology-specific variables we define the model variant as follows:

$$
\text { Patent }_{i, t}=\exp \left[\beta_{i} D^{i}\left(F I T_{t}^{\text {tech }}\right)+\beta_{j}\left(Z_{t}\right)+\alpha_{i}+\lambda_{t}\right]+\xi_{i, t}
$$

where FIT $_{i, t}^{\text {tech }}$ represent technology-specific variables. This model specification allows us to determine the innovation effects of FIT by each renewable technology.

Using our longer dataset (i.e., the data ranging from 1990 to 2009), we set up a further model for testing the effect of the different subsidy schemes under the SEG and the EEG. To this end, we generate period dummies which reflect the two policy environments from 1990-1999 (SEG) on the one hand and from 2000-2009 (EEG) on the other hand. The period dummies are interacted with installed capacity (CAP) which serves as our policy variable for the longer dataset:

\footnotetext{
${ }^{6}$ Note that we replace FIT data with data on installed capacity for the case of the longer dataset comprising both periods for SEG and EEG.
} 


$$
\text { Patent }_{i, t}=\exp \left[\beta_{1} D^{S E G}\left(C A P_{i, t}\right)+\beta_{2} D^{E E G}\left(C A P_{i, t}\right)+\beta_{j}\left(Z_{t}\right)+\alpha_{i}+\gamma_{t}\right]+\xi_{i, t}
$$

Finally, we define a model variant applied to the longer dataset where we interact also the $\mathrm{R} \& \mathrm{D}$ variable with the period dummies in order to test the innovation effects of R\&D under the SEG and EEG regimes.

\section{Empirical results}

Table 1 reports the estimated coefficients of the effects of FIT exclusively under the EEG framework (2000-2009). Model 1 and 2 shows the average innovation effects of FIT while model 3 and 4 lists the innovation impacts of technology-specific FIT. In Model 2 and 4, we include overall industrial private $R \& D$ expenditure as part of the control variables.

Table 1: Negative binomial estimates of the innovation effects of EEG-FIT

\begin{tabular}{|c|c|c|c|c|}
\hline & Model 1 & Model 2 & Model 3 & Model 4 \\
\hline Feed-in tariff (FIT) & $\begin{array}{l}0.027934 \\
{[0.017870]}\end{array}$ & $\begin{array}{l}0.028418 \\
{[0.018098]}\end{array}$ & & \\
\hline PhotoFIT & & & $\begin{array}{l}0.024021 \\
{[0.017353]}\end{array}$ & $\begin{array}{l}0.024176 \\
{[0.017782]}\end{array}$ \\
\hline WindFIT & & & $\begin{array}{c}-0.063888 \\
{[0.043412]}\end{array}$ & $\begin{array}{c}-0.064124 \\
{[0.043810]}\end{array}$ \\
\hline BioFIT & & & $\begin{array}{c}-0.369266 \\
{[0.075785]^{* *}}\end{array}$ & $\begin{array}{c}-0.369246 \\
{[0.075818]^{* *}}\end{array}$ \\
\hline GeoFIT & & & $\begin{array}{r}-0.041552 \\
{[0.042185]}\end{array}$ & $\begin{array}{c}-0.041805 \\
{[0.042644]}\end{array}$ \\
\hline HydroFIT & & & $\begin{array}{c}-0.675430 \\
{[0.123601]^{* *}}\end{array}$ & $\begin{array}{c}-0.675438 \\
{[0.123670]^{* *}}\end{array}$ \\
\hline Public $R \& D_{t-1}$ & $\begin{array}{l}0.017683 \\
{[0.016763]}\end{array}$ & $\begin{array}{l}0.015555 \\
{[0.017271]}\end{array}$ & $\begin{array}{c}-0.012078 \\
{[0.008807]}\end{array}$ & $\begin{array}{c}-0.012103 \\
{[0.008828]}\end{array}$ \\
\hline Private $R \& D_{t-1}$ & & $\begin{array}{l}0.000017 \\
{[0.000035]}\end{array}$ & & $\begin{array}{l}0.000001 \\
{[0.000020]}\end{array}$ \\
\hline$\Delta$ Elec. Consumption & $\begin{array}{c}0.040143 \\
{[0.015362]^{* *}}\end{array}$ & $\begin{array}{c}0.040585 \\
{[0.015399]^{* *}}\end{array}$ & $\begin{array}{c}0.024338 \\
{[0.006941]^{* *}}\end{array}$ & $\begin{array}{c}0.024293 \\
{[0.007027]^{* *}}\end{array}$ \\
\hline$\Delta$ Total patent count & $\begin{array}{c}-0.000173 \\
{[0.000126]}\end{array}$ & $\begin{array}{c}-0.000225 \\
{[0.000168]}\end{array}$ & $\begin{array}{c}-0.000061 \\
{[0.000057]}\end{array}$ & $\begin{array}{c}-0.000063 \\
{[0.000087]}\end{array}$ \\
\hline CPI of electricity $\mathrm{t}_{\mathrm{t}-1}$ & $\begin{array}{c}0.182145 \\
{[0.049237]^{* *}}\end{array}$ & $\begin{array}{c}0.185993 \\
{[0.050163]^{* *}}\end{array}$ & $\begin{array}{c}0.118213 \\
{[0.020847]^{* *}}\end{array}$ & $\begin{array}{c}0.118296 \\
{[0.020956]^{* *}}\end{array}$ \\
\hline Log likelihood & -142.25 & -142.14 & -121.84 & -121.84 \\
\hline Wald chi2 & 103.13 & 105.02 & 614.63 & 614.46 \\
\hline Nr. of observations & 45 & 45 & 45 & 45 \\
\hline Nr. of groups & 5 & 5 & 5 & 5 \\
\hline
\end{tabular}

Note: Robust standard errors in parentheses; $+p<0.1 ;{ }^{*} p<0.05 ;{ }^{* *} p<0.01$

The estimated coefficients at the aggregate technology-level for FIT in Model 1 and 2 are positive but statistically insignificant. Thus, our regression results suggest that the feed-in 
tariffs under the EEG have no significant positive impact on innovative activities in renewables. This result is at first glance surprising given that the FIT ensure above-market payments for a 20-year time horizon securing a market for possible innovation efforts. The results also suggest that domestic public $R \& D$ expenditure on renewable technologies does not trigger patenting activities. Given the high level of uncertainty, appropriability problems and financing difficulties that characterizes private $R \& D$ investments in high cost technologies, we would have expected public R\&D funding in renewables to significantly influence renewable innovation. Perhaps the innovative role of public R\&D funding is more evident at the early stages of technological development but not for the case of technologies that have seen significant advances as observed under the EEG. Our findings on the aggregate innovation impacts of the FIT and public R\&D expenditure do not confirm the results put forward in the more recent empirical literature on renewable technologies (Wangler 2012; Peters et al. 2012). Our estimates presented for models 3 and 4 highlight the importance of investigating innovation impacts for specific technologies rather than the aggregate technology level. We find insignificant innovation effects in the case of photovoltaic, wind and geothermal while the coefficients show even a significant negative effect in the case of biomass and hydro. ${ }^{7}$ We therefore warrant caution against a naïve interpretation of the estimates of models 1 and 2 in Table 1 that are based on the average of all the five technologies.

One economic explanation for the missing innovation impacts of FIT is the seemingly positive effects of EEG-FIT on incremental innovation but limited incentives for developing more radical technological innovations. The EEG in principle should encourage firms to increase production capacities which result in potential efficiency improvements through learning-by-doing and scale economies. The incremental innovative effect through learningby-doing and scale economies is however not captured in patent statistics which more generally reflect radical innovation. Moreover, the remuneration guaranteed by the EEG is calculated based on the average cost of the respective technology. Thus, for a potential innovator, the revenue from an (ex-post) cost-effective new technology is the same as the revenue generated through pre-existing technologies. As a consequence, it does not pay to embark on risk-involving investments in technological innovations. In effect, the EEG which primarily acts as a production subsidy for electricity provides greater incentive for exploitative investment rather than explorative investment by firms. The policy-induced

\footnotetext{
${ }^{7}$ Note that we obtain similar results by using installed capacity as the policy variable instead of FIT (see Appendix 5).
} 
market growth with its accompanying high profit margins creates incentives for firms with relatively mature technologies to shift resources from intensive, risky explorative research activities towards exploitative activities. The increase in exploitative behavior of firms also raises market entry barriers for less mature technologies, while at the same time facilitating lock-in effects in favor of established renewable energy technologies (Peters et al., 2012). The overall outcome is the absence of radical innovative effects of the EEG-FIT.

Market signals such as electricity prices and changes in electricity consumption appear to be important drivers of technological change in renewable technologies. We find statistically significant coefficients for electricity prices at the $1 \%$ level with a larger positive effect in all four regression models listed in Table 1. Expectations on future demand growth which is captured by changes in electricity consumption is also significant at the $1 \%$ level in all models (but with a relatively smaller positive effect). Industrial R\&D expenditure in Model 2 and 4 is however, insignificant. The estimated coefficient of all patents with Germany as priority country is also insignificant across all four models suggesting that the changes or variation in patenting activities in renewables cannot be attributed to the general propensity to patent in Germany.

In Table $2^{8}$, we report results for the regression models that use the longer dataset thereby covering both the SEG and the EEG regimes. We test the specific effects of the feed-in tariffs under the SEG and EEG as specified in Equation (3). As mentioned before, there are substantial differences in the feed-in regulations between SEG and EEG. Under the SEG, the feed-in tariff rates in a particular year are specified as a fixed share of the average electricity price that final consumers paid two years ago. The EEG on the other hand grants fixed tariffs with some annual degression over 20 years. The tariff rates under the EEG are much more differentiated by specific technologies with a particularly strong increase of the rate for photovoltaic. Both subsidy schemes are geared towards increasing the technology base of renewable technologies; hence, we use installed capacities to proxy the feed-in tariff regulations across the different systems.

The estimated coefficients in Models 5A and 5B which uses the longer dataset without controlling for differential subsidy regimes contradicts the results obtained in Models 1 and 2 for the shorter dataset with EEG only (see Table 1). Model 6A and 6B differentiates installed capacities by regulatory regime and Model 7A-8B also differentiate installed capacities by technology type with public R\&D differentiated into the regulatory regimes in Models 8A and

\footnotetext{
${ }^{8}$ Models 5B, 6B, 7B and 8B includes industry-wide private R\&D expenditures as a control variable
} 
8B. Interestingly, the estimated coefficient of capacity installation under the SEG in both Model 6A and Model 6B are statistically insignificant while it becomes significant in both models under the EEG. Thus, at the aggregate level, the changes in feed-in tariffs from SEG to EEG seems to have important implications for patenting activities which we do not observe in Table 1. However, just as the results for Model 3 and Model 4 in Table 1, our estimates (Model 7A-8B) reveal heterogeneity of effects across specific technologies. We find insignificant innovation impacts in the case of photovoltaic and geothermal while the coefficients show significant negative effect in the case of biomass and hydro. For wind, we observe significant positive innovation effects of feed-in tariffs.

Thus, the significant aggregate impact of the feed-in tariffs reported in Models 5A and 5B may largely be driven by the relatively stable results for wind. As to public R\&D funding, we find significant positive coefficients which may be mainly driven by the significant effect under the SEG regime (Model 8B) where public R\&D funding fostered technological development at an early stage. 
Table 2: Estimates with SEG/EEG and technology-specific dummies (with/without Private R\&D)

\begin{tabular}{|c|c|c|c|c|c|c|c|c|}
\hline & Model 5A & Model 5B & Model 6A & Model 6B & Model 7A & Model 7B & Model 8A & Model 8B \\
\hline Installed capacity & $\begin{array}{l}0.000075 \\
{[0.000022]^{* *}}\end{array}$ & $\begin{array}{l}0.000075 \\
{[0.000022]^{* *}}\end{array}$ & & & & & & \\
\hline Installed capacity $^{\text {seg }}$ & & & $\begin{array}{l}-0.000076 \\
{[0.000121]}\end{array}$ & $\begin{array}{c}-0.000076 \\
{[0.000121]}\end{array}$ & & & & \\
\hline Installed capacity $^{\text {eeg }}$ & & & $\begin{array}{l}0.000069 \\
{[0.000023]^{* *}}\end{array}$ & $\begin{array}{l}0.000069 \\
{[0.000023]^{* *}}\end{array}$ & & & & \\
\hline PhotoCAP & & & & & $\begin{array}{l}0.000044 \\
{[0.000028]}\end{array}$ & $\begin{array}{l}0.000044 \\
{[0.000028]}\end{array}$ & $\begin{array}{l}-0.000001 \\
{[0.000030]}\end{array}$ & $\begin{array}{l}0.000041 \\
{[0.000028]}\end{array}$ \\
\hline WindCAP & & & & & $\begin{array}{l}0.000049 \\
{[0.000013]^{* *}}\end{array}$ & $\begin{array}{l}0.000049 \\
{[0.000013]^{* *}}\end{array}$ & $\begin{array}{l}0.000021 \\
{[0.000015]}\end{array}$ & $\begin{array}{l}0.000043 \\
{[0.000015]^{* *}}\end{array}$ \\
\hline BioCAP & & & & & $\begin{array}{l}-0.000576 \\
{[0.000096]^{* *}}\end{array}$ & $\begin{array}{l}-0.000576 \\
{[0.000096]^{* *}}\end{array}$ & $\begin{array}{l}-0.000646 \\
{[0.000105]^{* *}}\end{array}$ & $\begin{array}{l}-0.000626 \\
{[0.000117]^{* *}}\end{array}$ \\
\hline GeoCAP & & & & & $\begin{array}{l}0.112365 \\
{[0.050202]^{*}}\end{array}$ & $\begin{array}{l}0.112365 \\
{[0.050202]^{*}}\end{array}$ & $\begin{array}{l}0.009773 \\
{[0.056564]}\end{array}$ & $\begin{array}{l}0.084861 \\
{[0.059096]}\end{array}$ \\
\hline HydroCAP & & & & & $\begin{array}{l}-0.000982 \\
{[0.000146]^{* *}}\end{array}$ & $\begin{array}{l}-0.000982 \\
{[0.000146]^{* *}}\end{array}$ & $\begin{array}{l}0.001573 \\
{[0.000837]+}\end{array}$ & $\begin{array}{l}-0.000981 \\
{[0.000146]^{* *}}\end{array}$ \\
\hline Public R\&D $\mathrm{D}_{\mathrm{t}-1}$ & $\begin{array}{l}0.028429 \\
{[0.009194]^{* *}}\end{array}$ & $\begin{array}{l}0.028429 \\
{[0.009194]^{* *}}\end{array}$ & $\begin{array}{l}0.027375 \\
{[0.009281]^{* *}}\end{array}$ & $\begin{array}{l}0.027375 \\
{[0.009281]^{* *}}\end{array}$ & $\begin{array}{l}0.016561 \\
{[0.006123]^{* *}}\end{array}$ & $\begin{array}{l}0.016561 \\
{[0.006123]^{* *}}\end{array}$ & & \\
\hline Public R\&D ${ }_{t-1}^{\text {seg }}$ & & & & & & & $\begin{array}{l}0.008060 \\
{[0.006083]}\end{array}$ & $\begin{array}{l}0.018181 \\
{[0.006529]^{* *}}\end{array}$ \\
\hline Public R\&D ${ }_{t-1}^{\text {eeg }}$ & & & & & & & $\begin{array}{l}0.000079 \\
{[0.007772]}\end{array}$ & $\begin{array}{l}0.011705 \\
{[0.008338]}\end{array}$ \\
\hline Private $R \& D_{t-1}$ & & $\begin{array}{l}0.001308 \\
{[0.003805]}\end{array}$ & & $\begin{array}{l}0.001293 \\
{[0.003857]}\end{array}$ & & $\begin{array}{l}-0.000029 \\
{[0.001898]}\end{array}$ & & $\begin{array}{l}-0.000707 \\
{[0.002060]}\end{array}$ \\
\hline$\Delta$ Elec. Consumption & $\begin{array}{l}0.055982 \\
{[0.019585]^{* *}}\end{array}$ & $\begin{array}{l}-0.007025 \\
{[0.180097]}\end{array}$ & $\begin{array}{l}0.055046 \\
{[0.019804]^{* *}}\end{array}$ & $\begin{array}{l}-0.007255 \\
{[0.182639]}\end{array}$ & $\begin{array}{l}0.045946 \\
{[0.009902]^{* *}}\end{array}$ & $\begin{array}{l}0.047322 \\
{[0.088308]}\end{array}$ & $\begin{array}{l}0.035853 \\
{[0.010466]^{* *}}\end{array}$ & $\begin{array}{l}0.076050 \\
{[0.094665]}\end{array}$ \\
\hline$\Delta$ Total patent count & $\begin{array}{l}-0.000166 \\
{[0.000135]}\end{array}$ & $\begin{array}{l}0.000557 \\
{[0.002139]}\end{array}$ & $\begin{array}{l}-0.000162 \\
{[0.000137]}\end{array}$ & $\begin{array}{l}0.000553 \\
{[0.002169]}\end{array}$ & $\begin{array}{l}-0.000146 \\
{[0.000062]^{*}}\end{array}$ & $\begin{array}{l}-0.000162 \\
{[0.001060]}\end{array}$ & $\begin{array}{l}-0.000126 \\
{[0.000066]+}\end{array}$ & $\begin{array}{l}-0.000530 \\
{[0.001146]}\end{array}$ \\
\hline CPI of electricity ${ }_{\mathrm{t}-1}$ & $\begin{array}{l}0.147175 \\
{[0.055893]^{* *}}\end{array}$ & $\begin{array}{l}-0.667702 \\
{[2.355227]}\end{array}$ & $\begin{array}{l}0.148482 \\
{[0.056751]^{* *}}\end{array}$ & $\begin{array}{l}-0.657250 \\
{[2.387715]}\end{array}$ & $\begin{array}{l}0.135231 \\
{[0.026976]^{* *}}\end{array}$ & $\begin{array}{l}0.153020 \\
{[1.174068]}\end{array}$ & $\begin{array}{l}0.147156 \\
{[0.029996]^{* *}}\end{array}$ & $\begin{array}{l}0.572095 \\
{[1.273846]}\end{array}$ \\
\hline Log likelihood & -303.14 & -303.14 & -302.26 & -302.26 & -253.44 & -253.44 & -267.99 & -253.05 \\
\hline Wald chi2 & 173.81 & 173.81 & 167.80 & 167.80 & 991.75 & 991.75 & 914.69 & 972.01 \\
\hline Nr. of observations & 95 & 95 & 95 & 95 & 95 & 95 & 95 & 95 \\
\hline Nr. of groups & 5 & 5 & 5 & 5 & 5 & 5 & 5 & 5 \\
\hline
\end{tabular}

Note: Robust standard errors in parentheses; $+p<0.1 ; * p<0.05 ; * * p<0.01$ 


\section{Conclusions}

Over the last decades policies to promote renewable energy have become increasingly popular in OECD countries. Policy makers embrace support schemes for renewable energy as a panacea to address the problem of climate change and spur innovation. A prime example is Germany with its feed-in tariffs to electricity produced from renewable energy sources. The feed-in tariffs were established under the Electricity Feed-in Law (Stromeinspeisungsgesetz SEG) in 1991, followed by the Renewable Energy Sources Act (Erneuerbaren Energien Gesetz - EEG) since 2000. The main pillars of the feed-in regulation is the grid operator's obligation to renewable energy sources (as opposed to electricity from conventional sources), and the payment of fixed tariffs. An unrestricted take-and-pay clause for fixed and high feedin tariffs led to a drastic expansion of renewable power production over the last decade. The cost of the feed-in tariff system amount to roughly 20 billion Euro in 2013 with the reallocation charge to be paid by electricity consumers rising to more than 6 cents $/ \mathrm{kWh}$ in 2014, i.e., roughly a fourth of the average household's consumer price.

The drastic cost increase of the EEG over the last years has triggered substantial criticism. Climate protection as a wide-spread argument for renewable energy promotion has no bite in the German case: Greenhouse gas emissions of the power sector together with other energyintensive industries are capped through an EU-wide emissions trading system. Explicit subsidies to renewable power production in Germany will thus simply reallocate emissions across energy-intensive industries in the EU. At the same time, feed-in tariffs increase the economy-wide cost of emission abatement thereby constituting an inefficient means of EU climate policy.

Another popular justification for feed-in tariffs are innovation externalities. In this paper we have scrutinized the innovation argument based on empirical data of the German feed-in regulation over the last two decades. Our regression results do not lend support to the proposition that German feed-in tariffs under the EEG spur innovation. In particular, our results indicate that photovoltaic which has received very high feed-in tariffs under the EEG does not engender innovative output. Given the drastic cost of the German EEG and missing empirical evidence on positive innovation impacts we caution against the appraisal of the German feed-in tariff system on innovation grounds. 


\section{References}

BDEW (2001 through 2009). Bundesverband der Energie- und Wasserwirtschaft e.V., EEG Jahresabrechnungen, Berlin.

Blundell, R., Griffith, R., and van Reenen, J., 1995. Dynamic Count Data Models of Innovation, Economic Journal 105, 333-345.

BMU, 2013. Development of renewable energy sources in Germany 2011, Federal Ministry for the Environment, Nature Conservation and Nuclear Safety. Available at: http://www.erneuerbare-energien.de/fileadmin/Daten_EE/Dokumente_PDFs_/ 20130328_hgp_e_ppt_2012_fin_bf.pdf

Böhringer, C., 2014. Two Decades of European Climate Policy: A Critical Appraisal. Review of Environmental Economics and Policy (forthcoming).

Böhringer, C., Tol, R. S. J. and Rutherford, T.F., 2009. The EU 20/20/2020 Targets: an Overview of The EMF22 Assessment. Energy Economics 31 (2), 268-273.

Cameron, A. and Trivedi, P., 1998. Regression analysis of count data. Cambridge University Press, Cambridge.

Danguy, J., de Rassenfosse, G. and van Pottelsberghe de la Potterie B. 2010. The R\&D-Patent relationship: An Industry Perspective. ECARES working paper 2010-038.

Dechezlepretre, A. and Glachant, M., 2013. Does foreign environmental policy influence domestic innovation? Evidence from the wind industry. Environmental and Resource Economics, DOI 10.1007/s10640-013-9705-4.

Dernis, H., Guellec, D., 2002. Using patent counts for cross-country comparisons of technology output. Science Technology Industry Review 7, 129-146.

Dernis, H. and Khan, M., 2004. Triadic patent families methodology. OECD science, technology and industry working papers 2004/2. Paris, France: OECD.

EEG, 2000/2004/2009/2012. Act on Granting Priority to Renewable Energy Sources (Renewable Energy Sources Act). The Federal Ministry for the Environment, Nature Conservation and Nuclear Safety, Germany

EIA, 2013. International Energy Statistics, available at: http://www.eia.gov/cfapps/ipdbproject/iedindex3.cfm?tid=2\&pid=2\&aid=2\&cid=CG1 \&syid=1990\&eyid=2010\&unit=BKWH

EPO, 2013. European Patent Office, EPO Worldwide Patent Statistical Database (PATSTAT), available at: http://www.epo.org/searching/subscription/raw/product-14-24.html

Frondel, M., Ritter, N., Schmidt, C. M., and Vance, C., 2010. Economic impacts from the promotion of renewable energy technologies: The German experience. Energy Policy 38, 4048-4056.

German Statistical Office, 2013. German Federal Statistical Office (Statistisches Bundesamt), Wiesbaden, Germany 
Griliches, Z., 1990. Patent Statistics as Economic Indicators: A Survey. Journal of Economic Literature 28(4), 1661-1707.

Hausman, J., Hall, B.H., and Griliches, Z., 1984. Econometric models for count data with an application to the patents-R\&D relationship. Econometrica 52, 909-938.

IEA, 2011. IEA Guide to Reporting Energy RD\&D Budget/Expenditure Statistics. June 2011 Edition.

IEA, 2013. RD\&D Budget. IEA Energy Technology RD\&D Statistics (database). Available at: doi: 10.1787/data-00488-en

Johnstone, N., Haščič, I., and Popp, D., 2010. Renewable Energy Policies and Technological Innovation: Evidence Based on Patent Counts. Environmental and Resource Economics 45(1), 133-155.

Lawless, J., 1987. Negative binomial and mixed poisson regression. Canadian Journal of Statistics 15 (3), 209-225.

Maddala, G.S., 1983. Limited-dependent and qualitative variables in econometrics. Cambridge University Press, Cambridge.

Mitchell, C., J. L. Sawin, G. R. Pokharel, D. Kammen, Z. Wang, S. Fifi ta, M. Jaccard, O. Langniss, H. Lucas, A. Nadai, R. Trujillo Blanco, E. Usher, A. Verbruggen, R. Wustenhagen, K. Yamaguchi, 2011: Policy, Financing and Implementation. In IPCC Special Report on Renewable Energy Sources and Climate Change Mitigation, Cambridge University Press, Cambridge, United Kingdom and New York, NY, USA.

OECD, 2013. The OECD Analytical BERD (ANBERD) Database. OECD/DSTI/EAS.

Peters, M., Schneider M., Griesshaber T., and Hoffmann V. H., 2012. The impact of technology-push and demand-pull policies on technical change - does the locus of policies matter? Research Policy 41(8), 1296-1308.

Schmookler, J., 1966. Invention and economic growth. Harvard University Press, Cambridge, MA.

Wakasugi, R. and Koyata, F., 1997. R\&D, Firm Size and Innovation Outputs: Are Japanese Firms Efficient in Product Development? Journal of Product Innovation Management 14 (5), 383-392,

Wangler, L.U., 2012. Renewables and innovation: did policy induced structural change in the energy sector effect innovation in green technologies? Journal of Environmental Planning and Management, 1-27.

Walz, R., Schleich, J., Ragwitz, M., 2011. Regulation, Innovation and Wind Power Technologies-An empirical analysis for OECD countries. Paper presented at DIME.

Wu, C and Mathews, J. A. (2012). Knowledge flows in the solar photovoltaic industry: Insights from patenting by Taiwan, Korea, and China, Research Policy 41(3), 524540. 


\section{Appendix}

Appendix 1: IPC codes for renewable energy technologies*

\begin{tabular}{|c|c|}
\hline Technologies & $\begin{array}{l}\text { Class/sub- } \\
\text { classes }\end{array}$ \\
\hline \multicolumn{2}{|l|}{ SOLAR PHOTOVOLTAIC } \\
\hline Roof covering aspects of energy collecting devices & E04D 13 \\
\hline $\begin{array}{l}\text { Processes or apparatus adapted for the manufacture or treatment of } \\
\text { semiconductor or solid state devices or of parts thereof }\end{array}$ & H01L 21 \\
\hline $\begin{array}{l}\text { Semiconductor devices sensitive to infra-red radiation, light, } \\
\text { electromagnetic radiation of shorter wavelength or corpuscular radiation } \\
\text { and adapted either for the conversion of the energy of such radiation } \\
\text { into electrical energy or for the control of electrical energy by such } \\
\text { radiation }\end{array}$ & H01L 31 \\
\hline $\begin{array}{l}\text { Generators in which light radiation is directly converted into electrical } \\
\text { energy }\end{array}$ & H02N 6 \\
\hline Single-crystal growth by pulling from a melt, e.g. Czochralski method & С30B 15 \\
\hline $\begin{array}{l}\text { Production of homogeneous polycrystalline material with defined } \\
\text { structure }\end{array}$ & С30B 28 \\
\hline $\begin{array}{l}\text { Single crystals or homogeneous polycrystalline material with defined } \\
\text { structure characterized by the material or by their shape }\end{array}$ & С30B 29 \\
\hline $\begin{array}{l}\text { Coating by vacuum evaporation, by sputtering or by ion implantation of } \\
\text { the coating forming material }\end{array}$ & C23C 14 \\
\hline $\begin{array}{l}\text { Chemical coating by decomposition of gaseous compounds, without } \\
\text { leaving reaction products of surface material in the coating, i.e. } \\
\text { chemical vapor deposition (CVD) processes }\end{array}$ & C23C 16 \\
\hline Organic semiconducting electrolytes & H01G 9/028 \\
\hline $\begin{array}{l}\text { Solid state devices using organic materials as the active part, or using a } \\
\text { combination of organic materials with other materials as the active part }\end{array}$ & H01L 51 \\
\hline \multicolumn{2}{|l|}{ WIND } \\
\hline Wind motors with rotation axis substantially in wind direction & F03D 1 \\
\hline $\begin{array}{l}\text { Wind motors with rotation axis substantially at right angle to wind } \\
\text { direction }\end{array}$ & F03D 3 \\
\hline Other wind motors & F03D 5 \\
\hline Controlling wind motors & F03D 7 \\
\hline Adaptations of wind motors for special use & F03D 9 \\
\hline $\begin{array}{l}\text { Details, component parts, or accessories not provided for in, or of } \\
\text { interest, apart from the other groups of this subclass }\end{array}$ & F03D 11 \\
\hline $\begin{array}{l}\text { Electric propulsion with power supply from force of nature, e.g. sun, } \\
\text { wind }\end{array}$ & B60L 8 \\
\hline $\begin{array}{l}\text { Effecting propulsion by wind motors driving water-engaging propulsive } \\
\text { elements }\end{array}$ & В63H 13 \\
\hline
\end{tabular}




\section{BIOMASS}

Solid fuels based on materials of non-mineral origin - animal or

C10L 5

vegetable

Engines operating on gaseous fuels from solid fuel - e.g. wood

F02B 43

Liquid carbonaceous fuels - organic compounds

C10L 1

Anion exchange - use of materials, cellulose or wood

B01J4 1

\section{GEOTHERMAL}

Other production or use of heat, not derived from combustion - using

F24J 3

natural or geothermal heat

Devices for producing mechanical power from geothermal energy

F03G 4

Electric motors using thermal effects

H02N 10

\section{HYDRO}

Engines of impulse type, i.e. turbines with jets of high-velocity liquid

F03B 1

impinging on bladed or like rotors, e.g. Pelton wheels

Machines or engines of reaction type; Parts or details peculiar thereto

F03B 3

Water wheels

F03B 7

Adaptations of machines or engines for special use; Combinations of

F03B 13

machines or engines with driving or driven apparatus

Controlling

F03B 15

Adaptations of machines or engines for special use; combinations of

F03B 13 machines wave or tide energy

* Based on Johnstone et al. (2010), Wu and Mathews (2012) and Wangler (2012)

\section{Appendix 2: Average technology-specific EEG-FIT}

\begin{tabular}{rrrrrr}
\hline Year & Photovoltaic & Wind & Biomass & Geothermal & Hydro \\
\hline 2000 & 50.62 & 9.1 & 10.23 & 8.95 & 7.67 \\
2001 & 50.62 & 9.1 & 10.23 & 8.95 & 7.67 \\
2002 & 48.09 & 9 & 10.13 & 8.95 & 7.67 \\
2003 & 45.69 & 8.9 & 10.03 & 8.95 & 7.67 \\
2004 & 50.58 & 8.9 & 14 & 8.95 & 7.67 \\
2005 & 54.53 & 8.815 & 13.77 & 15 & 9.67 \\
2006 & 51.8 & 8.73 & 13.54 & 15 & 9.67 \\
2007 & 49.21 & 8.645 & 13.32 & 15 & 9.67 \\
2008 & 46.75 & 8.475 & 13.1 & 15 & 9.67 \\
2009 & 43.01 & 12.1 & 14.7 & 16 & 12.67 \\
\hline
\end{tabular}

Sources: BDEW (2001 through 2009), EEG (2000, 2004, 2009) 
Appendix 3: Descriptive statistics of variables

\begin{tabular}{lrrrrl}
\hline Variable & Mean & Std. deviation & Min & Max & Unit \\
\hline Renewable patents & 29.25 & 49.23 & 0 & 261 & Counts \\
Total patents & 9037.70 & 4437.89 & 2246 & 14254 & Counts \\
Installed capacity & 3248.58 & 5332.39 & 0 & 25703 & MW \\
Public R\&D & 23.79 & 29.06 & 0 & 120.85 & Million US \$ \\
Elect. Consumption & 512.04 & 26.21 & 475.06 & 550.90 & Billion KWh \\
CPI of electricity & 69.76 & 10.65 & 59.20 & 96.90 & 2010 indexed to 100 \\
Feed-in tariff & 18.34 & 15.76 & 7.67 & 54.53 & EUR cent/KWh \\
\hline
\end{tabular}

Appendix 4: Correlation matrix among variables

\begin{tabular}{lccccccc}
\hline & $\begin{array}{c}\text { Renewable } \\
\text { patents }\end{array}$ & $\begin{array}{c}\text { Total } \\
\text { patents }\end{array}$ & $\begin{array}{c}\text { Installed } \\
\text { capacity }\end{array}$ & $\begin{array}{c}\text { Public } \\
\text { R\&D }\end{array}$ & $\begin{array}{c}\text { Elect. } \\
\text { Consumption }\end{array}$ & $\begin{array}{c}\text { CPI of } \\
\text { electricity }\end{array}$ & $\begin{array}{c}\text { Feed-in } \\
\text { tariff }\end{array}$ \\
\hline Renewable patents & 1.0000 & & & & & & \\
Total patents & 0.3750 & 1.0000 & & & & & \\
Installed capacity & 0.6018 & 0.3943 & 1.0000 & & & & \\
Public R\&D & 0.4274 & -0.0620 & -0.0458 & 1.0000 & & & \\
Elect. Consumption & 0.3541 & 0.8555 & 0.4038 & -0.0418 & 1.0000 & & \\
CPI of electricity & 0.5482 & 0.6707 & 0.4845 & 0.0435 & 0.6767 & 1.0000 & \\
Feed-in tariff & 0.4854 & -0.0089 & -0.2430 & 0.8997 & 0.0392 & 0.0490 & 1.0000 \\
\hline
\end{tabular}


Appendix 5: Negative binomial estimates of the innovative effect of EEG using installed capacity to proxy FIT

\begin{tabular}{|c|c|c|c|c|}
\hline & CAP1 & CAP2 & Tech. CAP & $\begin{array}{l}\text { Tech. } \\
\text { CAP/R\&D }\end{array}$ \\
\hline Installed capacity & $\begin{array}{l}0.000019 \\
{[0.000029]}\end{array}$ & $\begin{array}{l}0.000025 \\
{[0.000030]}\end{array}$ & & \\
\hline PhotoCAP & & & $\begin{array}{l}0.000028 \\
{[0.000027]}\end{array}$ & $\begin{array}{l}0.000034 \\
{[0.000027]}\end{array}$ \\
\hline WindCAP & & & $\begin{array}{l}0.000016 \\
{[0.000022]}\end{array}$ & $\begin{array}{l}0.000014 \\
{[0.000026]}\end{array}$ \\
\hline BioCAP & & & $\begin{array}{l}-0.000344 \\
{[0.000079]^{* *}}\end{array}$ & $\begin{array}{l}-0.000338 \\
{[0.000099]^{* *}}\end{array}$ \\
\hline GeoCAP & & & $\begin{array}{l}0.010094 \\
{[0.047396]}\end{array}$ & $\begin{array}{l}0.012821 \\
{[0.054121]}\end{array}$ \\
\hline HydroCAP & & & $\begin{array}{l}-0.001705 \\
{[0.000507]^{* *}}\end{array}$ & $\begin{array}{l}-0.001661 \\
{[0.000708]^{*}}\end{array}$ \\
\hline Public $R \& D_{t-1}$ & $\begin{array}{l}0.017108 \\
{[0.015602]}\end{array}$ & $\begin{array}{l}0.013302 \\
{[0.016391]}\end{array}$ & $\begin{array}{l}-0.005761 \\
{[0.007424]}\end{array}$ & $\begin{array}{l}-0.012103 \\
{[0.008828]}\end{array}$ \\
\hline Private $\mathrm{R} \& \mathrm{D}_{\mathrm{t}-1}$ & & $\begin{array}{l}0.000023 \\
{[0.000036]}\end{array}$ & $\begin{array}{l}-0.000004 \\
{[0.000019]}\end{array}$ & $\begin{array}{l}-0.000004 \\
{[0.000020]}\end{array}$ \\
\hline$\Delta$ Elec. Consumption & $\begin{array}{l}0.041642 \\
{[0.015456]^{* *}}\end{array}$ & $\begin{array}{l}0.042450 \\
{[0.015565]^{* *}}\end{array}$ & $\begin{array}{l}0.030260 \\
{[0.006202]^{* *}}\end{array}$ & $\begin{array}{l}0.036986 \\
{[0.010936]^{* *}}\end{array}$ \\
\hline$\Delta$ Total patent count & $\begin{array}{l}-0.000197 \\
{[0.000128]}\end{array}$ & $\begin{array}{l}-0.000254 \\
{[0.000159]}\end{array}$ & $\begin{array}{l}-0.000067 \\
{[0.000081]}\end{array}$ & $\begin{array}{l}0.000178 \\
{[0.000213]}\end{array}$ \\
\hline CPI of electricity $\mathrm{t}_{\mathrm{t}-1}$ & $\begin{array}{l}0.173271 \\
{[0.051139]^{* *}}\end{array}$ & $\begin{array}{l}0.176241 \\
{[0.052187]^{* *}}\end{array}$ & $\begin{array}{l}0.113417 \\
{[0.020452]^{* *}}\end{array}$ & $\begin{array}{l}0.110306 \\
{[0.019649]^{* *}}\end{array}$ \\
\hline Photo $R \& D_{t-1}$ & & & & $\begin{array}{l}-0.003252 \\
{[0.009706]}\end{array}$ \\
\hline Wind $R \& D_{t-1}$ & & & & $\begin{array}{l}-0.006885 \\
{[0.008045]}\end{array}$ \\
\hline Bio $R \& D_{t-1}$ & & & & $\begin{array}{l}-0.004683 \\
{[0.010608]}\end{array}$ \\
\hline Geo $R \& D_{t-1}$ & & & & $\begin{array}{l}-0.005001 \\
{[0.013098]}\end{array}$ \\
\hline Hydro $R \& D_{t-1}$ & & & & $\begin{array}{l}-0.051219 \\
{[0.033624]}\end{array}$ \\
\hline Log likelihood & -143.14 & -142.93 & -115.45 & -114.31 \\
\hline Wald chi2 & 112.65 & 112.98 & 667.13 & 689.76 \\
\hline Nr. of observations & 45 & 45 & 45 & 45 \\
\hline Nr. of groups & 5 & 5 & 5 & 5 \\
\hline
\end{tabular}

Note: Robust standard errors in parentheses; $+p<0.1$; ${ }^{*} p<0.05 ;{ }^{* *} p<0.01$ 